\title{
Evaluations of Antioxidant Effects of Selected Medicinal Plant Extracts Claimed to Treat Kidney Stone Disease
}

\author{
Tilahun Alelign $^{1, *}$, Asfaw Debella ${ }^{2}$, Beyene Petros ${ }^{1}$
}

\section{Tilahun Alelign ${ }^{1, *}$, Asfaw Debella $^{2}$, Beyene Petros ${ }^{1}$}

\section{'Addis Ababa University, Addis Ababa,} ETHIOPIA.

${ }^{2}$ Ethiopian Public Health Institute, Traditional and Modern Drug Research, ETHIOPIA.

\section{Correspondence}

\section{Dr. Tilahun Alelign}

Addis Ababa University, Addis Ababa, ETHIOPIA.

Phone no: +251-912038343

E-mail: tilaalelign@gmail.com

\section{History}

- Submission Date: 03-10-2020:

- Review completed: 21-11-2020;

- Accepted Date: 15-12-2020.

\section{DOI : 10.5530/fra.2020.2.12}

Article Available online

http://www.antiox.org

\section{Copyright}

(C) 2020 Phcog.Net. This is an openaccess article distributed under the terms of the Creative Commons Attribution 4.0 International license.

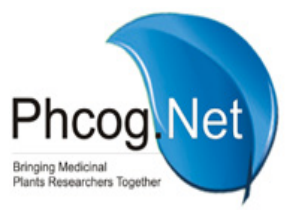

\begin{abstract}
Introduction: Free radicals are capable of inducing oxidative damage, which causes various human diseases. However, antioxidants reduce the risk of diseases related to reactive oxygen species. Medicinal plants such as Achyranthes aspera leaves, Satureja punctata aerial parts, Aloe pulcherrima gel, Gomphocarpus fruticosus leaves and Commiphora myrrha resins were claimed to treat various ailments including urolithiasis in Ethiopia. Objectives: This study was intended to determine phytochemicals and antioxidant activities of the aforementioned plants. Materials and Methods: Plants were collected and the aqueous crude extracts were prepared. Phytochemicals were screened qualitatively and DPPH(2,2-diphenyl-1-picrylhydrazyl) radical scavenging assay was measured at $517 \mathrm{~nm}$ using UV-Vis spectrophotometry. Data were analyzed statistically using one-way ANOVA, Dunnett's comparison test of the Graph Pad Prism version 6. Results: The plant extracts exhibited various phytochemicals such as phenols, flavonoids and tannins, while these were absent in C. myrrha. Steroids and terpenoides were absent in A. pulcherrima and $G$. fruticosus extracts, respectively. DPPH scavenging capacities of S. punctata, G. fruticosus, A. pulcherrima and A. aspera aqueous extracts were $92.3 \%$, $81.6 \%, 72.3 \%$ and $54.9 \%$, respectively compared to control (Ascorbic acid) showed 87.6\%, $94.5 \%, 92.3 \%$ and $95.6 \%$, respectively at inhibitory concentrations of $0.20 \mathrm{mg} / \mathrm{ml}, 0.78 \mathrm{mg} /$ $\mathrm{ml}, 3.13 \mathrm{mg} / \mathrm{ml}$ and $12.5 \mathrm{mg} / \mathrm{ml}$, respectively. The $I_{50}$ antioxidant values of $S$. punctata, $A$. pulcherrima, $G$. fruticosus, and $A$. aspera extracts were $0.01 \pm 0.003 \mathrm{mg} / \mathrm{ml}, 0.42 \pm 0.047$ $\mathrm{mg} / \mathrm{ml}, 1.64 \pm 0.147 \mathrm{mg} / \mathrm{ml}$, and $13.51 \pm 1.08 \mathrm{mg} / \mathrm{ml}$, respectively compared to Ascorbic acid $(0.03 \pm 0.007 \mathrm{mg} / \mathrm{ml})$. Conclusion: The phytoconstituents in S. punctata aqueous extract has the best capability to scavenge DPPH free radicals. Future characterizations of compounds responsible for the antioxidant activities will be required.
\end{abstract}

Key words: Antioxidant activity, DPPH, Free radicals, Medicinal plants, Phytochemicals.

\section{INTRODUCTION}

Excess oxygen could result in oxidative damage, which may lead to death due to its role in the reduction of certain products into free radicals. The formation of free radicals (highly reactive oxygen species) through the activity of the respiratory chain in the mitochondria is part of the cell's normal metabolic process, including detoxification process and immune defenses. ${ }^{1}$ Oxidative stress can be initiated if the generation of free radicals exceeds the body's ability to protect the effect of antioxidants. The excessive generation of free radicals such as nitric oxide and peroxynitrite (an unstable structural isomer of nitrate), ${ }^{2}$ superoxide anions, hydrogen peroxides and hydroxyl radicals are capable of inducing oxidative damage to the body. ${ }^{1,3}$ Radicals cause damage to various cellular macromolecules such as DNA, proteins and lipids, which trigger various human chronic diseases. ${ }^{2,4}$ However, the proper physiological functions of the body could be maintained by bodies endogenous antioxidant systems, ${ }^{5}$ and by ingestion of exogenous antioxidants. ${ }^{4}$ Therefore, adequate antioxidant defense within and outside cells is important to offer protection against oxidative damage. $^{6}$

In aerobic organisms, the defense system against free radicals is provided by scavengers, which act as antioxidants. This functions by donating an electron to free radicals, thereby, the paired electrons stabilized. Human cells have an array of protecting mechanisms by preventing the production of free radicals through enzymatic and non-enzymatic antioxidants. The first antioxidant defense may involve enzymes such as superoxide dismutase (SOD), catalase (CAT) and glutathione peroxidase (GPX); whereas the non-enzymatic mechanisms include nutrients and minerals. ${ }^{78}$ The glutathione (GSH) detoxifies hydroxyl radicals. ${ }^{9}$ The activities of antioxidant enzymes were reduced due to defects in the antioxidant defense system. ${ }^{10}$ However, the antioxidant constituents of plants might restore

Cite this article: Alelign T, Debella A, Petros B. Evaluations of Antioxidant Effects of Selected Medicinal Plant Extracts Claimed to Treat Kidney Stone Disease. Free Radicals and Antioxidants. 2020;10(2):63-8. 
the renal antioxidant enzymes, which protect from renal cell injury. ${ }^{11}$ The non-enzymatic antioxidants can be classified as water-soluble and lipid-soluble depending on whether they act primarily in the aqueous phase or in the lipophilic region of the cell membrane. Ascorbic acid (vitamin C) is a naturally occurring antioxidant found in medicinal plants, vegetables, fruits and whole grains. The hydrophilic antioxidants include Vitamin C and certain polyphenol flavonoid groups; whereas the lipophilic antioxidants include ubiquinols, retinoids, carotenoids, apocynin and procyanidins. ${ }^{12} \mathrm{DPPH}$ (2,2-diphenyl-1-picrylhydrazyl) is an organic compound, which is a dark-red colored crystalline powder composed of free-radical molecules. ${ }^{13} \mathrm{DPPH}$ assay is a widely used model to evaluate antioxidants because of its ease of use and reproducibility. ${ }^{14,15}$ In the DPPH assay, the initial electron transfer occurs very quickly and the subsequent hydrogen transfer occurs more slowly and depends on the hydrogen-bond accepting solvents. DPPH free radical scavenging effects of antioxidants is due to their hydrogen atom-donating ability. ${ }^{16,17}$ In antioxidant assays, a strong hydrogen-bond accepting solvents such as methanol and ethanol are usually used. ${ }^{18}$ Electron transfer assays measure the reducing ability of the substrate (antioxidant), whereas the hydrogen transfer assays measure hydrogen donating ability of the substrate. Previous studies reported that assays that measure hydrogen transfer would be preferable to assays that measure electron transfer. ${ }^{19}$ If free radicals have been scavenged by plant extracts, DPPH solutions could be changed from violet to yellow color; which is a decolorization effect. $^{20}$

Absorbance can be measured after the reactions of antioxidants with $\mathrm{DPPH}$, which are dissolved in methanol or ethanol..$^{13} \mathrm{DPPH}$ radical has a maximum UV-Vis spectrophotometry absorption in the range between $515 \mathrm{~nm}$ and $519 \mathrm{~nm} \cdot{ }^{13,21}$ The reduction in absorbance of $\mathrm{DPPH}$ radicals in the solution revealed the actions of antioxidant agents. ${ }^{17,22}$ Therefore, the ability of the plant extracts to scavenge DPPH free radicals could contribute to the inhibition of the inflammatory processes. ${ }^{23}$ The polyphenol of plant extracts is an excellent antioxidant, which act by hydrogen donation of their phenolic hydroxyl group to stop free radical chain reactions. ${ }^{24}$ The synthetic antioxidants such as butylated hydroxytoluene and butylated hydroxyanisole have recently been reported to be dangerous for human health. ${ }^{4}$ Therefore, searching an effective, non-toxic and natural antioxidant could be an effective treatment option to manage renal oxidative stress.

In Ethiopia, medicinal plants like Achyranthes aspera L. and Satureja punctata (Benth.) Briq. ${ }^{25,26}$ Aloe pulcherrima-Gilbert and Sebsebe; ${ }^{26}$ Gomphocarpus fruticosus (L.) Ait.f, (key informant); and Commiphora myrrha (Nees) Engl. ${ }^{26}$ have been claimed to treat various diseases including kidney stones. Before the commencement of this work, the insufficiency of scientific literature was assessed in relation to phytochemical analysis and antioxidant effects. Therefore, the present study was aimed at providing information on phytochemicals and the in vitro DPPH scavenging activities of the aforementioned plant extracts.

\section{MATERIALS AND METHODS}

\section{Medicinal Plant Collection and preparation of Crude Extracts}

The A. aspera L. leaves were collected from Addis Ababa University "Arat kilo" Campus; S. punctata (Benth.) Briq. aerial parts at "Entoto" forest region, Northwest to Addis Ababa; and A. pulcherrima Gilbert and Sebsebe gel were collected from Ankober District of North Shewa Zone. the leaf of Gomphocarpus fruticosus (L.) Ait.f (Asclepiadaceae) collected at Bole Bulbula around "93 Mazoria" Addis Ababa; whereas the resins of Commiphora myrrha (Nees) Engl. (Burseraceae) were purchased from Merkato market, Addis Ababa. Specimens of these plants were deposited in the National Herbarium of Addis Ababa University (AAU) for future reference.

The plant materials were cleaned thoroughly with tap water to remove contaminants and dried in shed at room temperature from 2 to 3 weeks in the Biomedical Sciences laboratory, AAU. The dried plant parts and resins were finely powdered using a kitchen grinder (Mortar and Pestle, sized about 9 inches in diameter). The powders were put through a sieve of 3 mesh sizes so as to filter a gross solid matter. The gel of $A$. pulcherrima plant was collected by spilling-out its fresh leaves with the knife. This gel is highly moisturizing content of the Aloe plant, which is used for various medicinal uses.

The extracts were prepared using a procedure similar to that often used by traditional healer's or patients, with some minor modifications. The plant powders were soaked in distilled water, which was placed on a shaker for $72 \mathrm{hr}$. The mixture was filtered through cotton/gauze, then through Whatman filter paper number 1 (pore size: $11 \mu \mathrm{m}$ ) to remove fine solid plant particles or insoluble constituents. The entire extracts were concentrated to dryness using lyophilizer under reduced pressure. Then, the semi-solid concentrates poured into a glass petri-plates and allowed to completely dry in water bath adjusted to $45^{\circ} \mathrm{C}$. The final dried extracts were collected and stored in labeled sterile bottles covered with air-tight stopper and kept in freezer on $-20^{\circ} \mathrm{C}$ until used in the experiments.

\section{Phytochemical Screening}

In the present study, a preliminary phytochemical screening of the selected medicinal plants of the aqueous crude extracts was carried out for qualitative estimations of phytoconstituents. ${ }^{27}$ The presence of the following secondary metabolites was evaluated using the respective methods as alkaloids, ${ }^{28,29}$ phenol, ${ }^{30}$ flavonoids, ${ }^{31}$ tannins, ${ }^{32,33}$ steroids,${ }^{34}$ terpenoids, ${ }^{35}$ saponin, ${ }^{36}$ Glycosides, ${ }^{37}$ and steroidal glycosides. ${ }^{34}$

\section{Chemicals and Reagents}

The chemicals used in the present work were analytical grade purchased from local distributors of Ethiopia. The procurement of the required supplies, chemicals and reagents including petroleum ether, chloroform, ethyl acetate, butanol and ethanol were from Wisteam PLC; DPPH (2,2-diphenyl-1-picrylhydrazyl) and sodium chloride $(\mathrm{NaCl})$ were purchased from Micron International Trading House PLC. Ascorbic acid was obtained from Food Sciences Department of AAU, which was purchased from Micron International Trading House PLC, Addis Ababa, Ethiopia.

\section{DPPH Radical Scavenging Activity}

DPPH (2,2-diphenyl-1-picrylhydrazyl) free radical scavenging potentials of plant extracts were determined using similar methods to ${ }^{11}$ and ${ }^{38}$ with minor modifications. DPPH is commercially available radical capable of accepting an electron (hydrogen) to become stable molecule, with a maximum UV-Vis spectrophotometry absorption at $517 \mathrm{~nm}$ for 30 min. ${ }^{18,39} \mathrm{DPPH}$ colorimetric assay, the original deep violet color of DPPH solution converts into a stable yellow-white color in the presence of the potent antioxidants. ${ }^{21}$ The basic chemical reaction of DPPH in the presence of an electron donating antioxidant is represented as: DPPH + $\mathrm{AH} \rightarrow \mathrm{DPPH}-\mathrm{H}+\mathrm{A}^{*} \cdot{ }^{21,40}$

The antioxidant activities of the various concentrations $(0.20,0.39,0.78$, $1.56,3.13,6.25,12.50,25,50,100 \mathrm{mg} / \mathrm{ml})$ of plant extracts compared to standard drugs were examined. Ascorbic acid was used as a reference drug. The working solution was prepared by diluting the stock solution to a series of concentrations. A solution of $0.5 \mathrm{mM} \mathrm{DPPH}\left(\mathrm{C}_{18} \mathrm{H}_{12} \mathrm{~N}_{5} \mathrm{O}_{6}\right.$ Molecular weight: 394.32$)(0.19 \mathrm{mg} / \mathrm{ml})$ in methanol was prepared. Then, $2 \mathrm{ml}$ of DPPH solution was mixed with $1 \mathrm{ml}$ of plant extract prepared in methanol. The mixture was vortexed thoroughly and left 
in the dark chamber at room temperature for $30 \mathrm{~min}$ and measured spectrophotometrically at $517 \mathrm{~nm}$ for light transmittance (absorbance). These were analyzed in a quartz cuvette (optical path: $10 \mathrm{~mm}$ and size: $4 \mathrm{ml}$ ) at room temperature. The ability of the plant extract to scavenge DPPH radical was calculated as follows.

DPPH radical scavenging activity $(\%)=[($ Control - Sample $) /$ Control $]$ $\times 100$, where; Control refers to the absorbance of DPPH radical plus methanol; Sample $=$ the absorbance of DPPH radical plus the extract/ Ascorbic acid. Methanol was used as a blank reference. Each test was performed in triplicate.

The antioxidant activities of $A$. aspera, S. punctata, A. pulcherrima, G. fruticosus and $C$. myrrha extracts were assessed at various concentrations ranging from 0.02 to $100 \mathrm{mg} / \mathrm{ml}$. According to the United States food and drug administration (FDA), the half maximal inhibitory concentration $\left(\mathrm{IC}_{50}\right)$ represents the concentration of a drug, which is required for $50 \%$ inhibition under in vitro test. ${ }^{[41,52]}$ The dose-response experiments were performed 3 times for each extract/standard control, and the mean $\mathrm{IC}_{50}$ \pm SD was calculated. The percent of control was calculated as absorbance units in the presence of Ascorbic acid.

\section{Statistical Analysis}

Data were analyzed using Graph Pad Prism version 6 Software (Graph Pad Software, San Diego, CA, USA). One-way analysis of variance (ANOVA) followed by Dunnett's comparison test was performed to compare between the positive control (ascorbic acid) and plant extracts groups for antioxidant evaluations. Nonlinear regression analysis was used to calculate the $\mathrm{IC}_{50}$ values for all dose-response curves. The data values were expressed as mean \pm standard deviation (SD) of three replicates. Values of $p<0.05$ was considered statistically significant.

\section{RESULTS}

\section{Phytochemical Analysis}

Preliminary phytochemical analysis of the selected medicinal plant aqueous extracts resulted in the identification of the following constituents (Table 1).

\section{DPPH radical scavenging assays}

Ascorbic acid (vitamin C), the positive control revealed the highest DPPH radical scavenging activity with $87.6 \%$ reductions at concentration of $0.20 \mathrm{mg} / \mathrm{ml}$, and $98.4 \%$ at $100 \mathrm{mg} / \mathrm{ml}$ concentration. The antioxidant activity of $S$. punctata extract was $92.3 \%$ inhibition at $0.20 \mathrm{mg} / \mathrm{ml}$, which was higher than the effect of ascorbic acid $(87.6 \%)$ at $0.20 \mathrm{mg} / \mathrm{ml}$. The antioxidant activity of S. punctata at dose $100 \mathrm{mg} / \mathrm{ml}$ was $88.5 \%$, which was lower than ascorbic acid (98.4\%), although not statistically significant. In general, $S$. punctata extract was a strong antioxidant equivalent to ascorbic acid. The antioxidant activity of A. pulcherrima extract was $72.3 \%$ at $0.78 \mathrm{mg} / \mathrm{ml}$, which was significantly different from that of ascorbic acid $(94.5 \%)(P<0.01)$. However, as the concentrations of $A$. pulcherrima extract increased beyond $6.25 \mathrm{mg} / \mathrm{ml}(88.4 \%)$, its antioxidant activity declined to $69.7 \%$ at $100 \mathrm{mg} / \mathrm{ml}$ significantly lower than ascorbic acid $(P<0.001)$. G. fruticosus showed a scavenging potential of $81.6 \%$ at $3.13 \mathrm{mg} / \mathrm{ml}$, which was significantly different from ascorbic acid $(92.3 \%)(P<0.05)$. In addition, $G$. fruticosus scavenged free radicals by $93 \%$ at $12.50 \mathrm{mg} / \mathrm{ml}$, which was not significantly different from the positive control, ascorbic acid (92.8\%).

The antioxidant activity of $A$. aspera leaves (48.9\%) at $12.50 \mathrm{mg} / \mathrm{ml}$ was significantly lower than ascorbic acid (95.6\%) at the same concentration. Similarly, the antioxidant activity of $A$. aspera inflorescences was $54.9 \%$ at $6.25 \mathrm{mg} / \mathrm{ml}$ compared to ascorbic acid $(94.1 \%)(P<0.001)$. DPPH scavenging potentials of $A$. aspera inflorescences was $71.6 \%$ compared to ascorbic acid $(95.5 \%)$ at $25 \mathrm{mg} / \mathrm{ml}(P<0.001)$. The antioxidant activity of $A$. aspera leaves increased in a concentration dependent manner and it was $94.6 \%$ at $100 \mathrm{mg} / \mathrm{ml}$ equivalent to ascorbic acid (98.4\%). However, A. aspera roots extract didn't possess antioxidant activity. DPPH radical scavenging activity of C. myrrha extract was $15.9 \%$ at $100 \mathrm{mg} / \mathrm{ml}$, which was significantly lower than that of ascorbic acid $(P<0.001)$. The IC50 antioxidant values of $S$. punctata, A. pulcherrima, G. fruticosus, A. aspera and $C$. myrrha extracts were $0.01 \pm 0.003 \mathrm{mg} / \mathrm{ml}, 0.42 \pm 0.047 \mathrm{mg} / \mathrm{ml}, 1.64$ $\pm 0.147 \mathrm{mg} / \mathrm{ml}, 13.51 \pm 1.08 \mathrm{mg} / \mathrm{ml}$ and nill, respectively, compared to Ascorbic acid $(0.03 \pm 0.007 \mathrm{mg} / \mathrm{ml})$ (Figure 1).

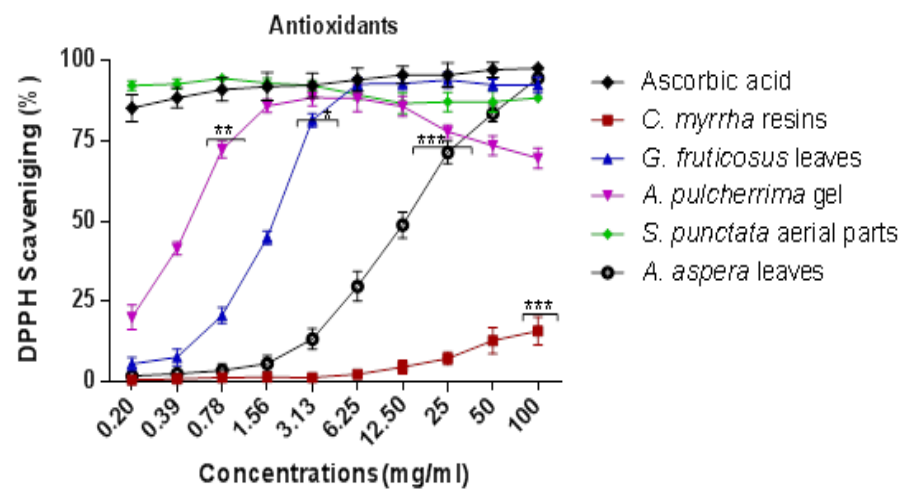

Figure 1: DPPH scavenging activities (\%) of aqueous extracts of test plants at various concentrations. C. myrrha, G. fruticosus, S. punctata, A. pulcherrima and $A$. aspera extract as compared to the positive controls-ascorbic acid. Data were based on mean \pm SD of three independent observations. ${ }^{*} P<0.05$, ${ }^{* *} P$ $<0.01,{ }^{* * *} P<0.001$ statistically significant compared to the control group.

Table 1: Phytochemical screening of the crude aqueous extracts of medicinal plants.

\begin{tabular}{|c|c|c|c|c|c|c|c|c|c|c|}
\hline \multirow[b]{2}{*}{ 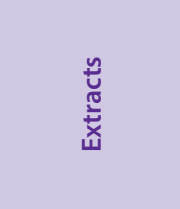 } & \multicolumn{10}{|c|}{ Chemical constituents } \\
\hline & $\begin{array}{l}\frac{n}{0} \\
\frac{c}{d} \\
\frac{c}{\alpha}\end{array}$ & $\begin{array}{l}\frac{n}{0} \\
\frac{0}{0} \\
\frac{0}{0} \\
\frac{\pi}{4}\end{array}$ & $\frac{\stackrel{n}{\frac{c}{c}}}{\stackrel{\frac{c}{n}}{n}}$ & $\begin{array}{l}\frac{n}{0} \\
\frac{0}{0} \\
\frac{1}{d} \\
\dot{n}\end{array}$ & 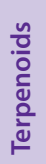 & 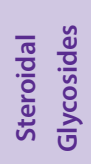 & $\begin{array}{l}\frac{y}{\frac{0}{0}} \\
\frac{0}{\sqrt[0]{0}} \\
\frac{y}{4}\end{array}$ & $\begin{array}{l}\stackrel{n}{\frac{n}{c}} \\
\frac{0}{0} \\
\stackrel{\circ}{n} \\
\text { ñ }\end{array}$ & 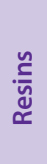 & 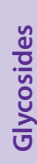 \\
\hline A. aspera & + & + & + & + & + & + & + & + & - & - \\
\hline S. punctata & + & + & + & + & + & + & - & + & + & - \\
\hline A. pulcherrima & + & + & + & - & + & - & - & - & - & + \\
\hline G. fruticosus & + & + & + & + & - & + & + & + & - & + \\
\hline C. myrrha & - & - & - & + & + & + & - & - & - & + \\
\hline
\end{tabular}




\section{DISCUSSION}

The antioxidant constituents of plant extracts might restore the antioxidant enzymes of kidneys, which help to prevent renal cell injury. ${ }^{11}$ Antioxidants have been reported to reconcile free radicals by directly reacting and quenching their catalytic metal ions. ${ }^{42}$ In other words, antioxidants neutralize the damaging effects of free radicals on tissues by donating electrons at the site of injury. ${ }^{43}$ Previous studies reported that DPPH scavenging potentials of whole leaves extract of Aloe ferox was concentration dependent in which hydrogen donating compounds in the extract might increase. ${ }^{44}$ In the present study, S. punctata extract has scavenged DPPH free radicals as postulated that it may react with hydrogen donors. ${ }^{13}$

Previous phytochemical studies on other plants had reported that flavonoids, ${ }^{45}$ saponins and terpenoids ${ }^{46}$ and phenols ${ }^{47}$ exhibited antioxidant activities. In line with these studies, $S$. punctata aqueous extract possesses phytochemicals including phenols, flavonoids, saponins and terpenoids showing antioxidant effects similar to ascorbic acid. Similarly, the aqueous extract of $A$. pulcherrima consists of phenols, flavonoids and terpenoids, whereas G. fruticosus extract possesses phenols and flavonoids, which shows DPPH radical scavenging activities. Therefore, targeting reductions in oxidative stress would be therapeutic options in the treatment of urolithiasis. The present in vitro study showed that the DPPH radical scavenging activity of half minimum inhibitory concentration $\left(\mathrm{IC}_{50}\right)$ of $S$. punctata, A. pulcherrima, $G$. fruticosus, A. aspera and C. myrrha aqueous extracts were $0.01 \pm 0.003$ $\mathrm{mg} / \mathrm{ml}, 0.42 \pm 0.047 \mathrm{mg} / \mathrm{ml}, 1.64 \pm 0.147 \mathrm{mg} / \mathrm{ml}, 13.51 \pm 1.08 \mathrm{mg} / \mathrm{ml}$ and nill, respectively. This indicates that $S$. punctata extract effectively scavenges DPPH radicals at the lower concentration than the other plants.

The antioxidant properties of test extracts may be potential contributors for lithotriptic effects, ${ }^{48}$ and $S$. punctata aqueous extract was found to be the most potent antioxidant comparable to ascorbic acid in the present study. As reported earlier, the presence of antioxidant metabolites like flavonoids and phenols might be responsible for antiurolithiatic effects. ${ }^{49}$ These were present in S. punctata, A. pulcherrima and G. fruticosus aqueous extracts phytochemical analysis that would further strengthen their use to treat urolithiasis-induced oxidative stress. Furthermore, the antiurolithiatic activities of $S$. punctata, A. pulcherrima and G. fruticosus aqueous extracts might be due to the disintegrations of mucoproteins by saponins and tannins found in the present study. The IR analysis of $G$. fruticosus fraction II revealed the presence of hydroxyl groups attached to the aromatic ring structures, which may be responsible for the antioxidant properties quenching free radicals as supported by earlier studies..$^{50,51}$

Furthermore, it was also reported that the steroidal constituents of medicinal plants possess antiurolithiatic activities, suggesting that macromolecules may inhibit $\mathrm{CaOx}$ nucleation in the human urine, ${ }^{52}$ which was found in both $S$. punctata and G. fruticosus aqueous extracts. Although our in vitro antioxidant data could not be extrapolated into in vivo data, it gave an insight for the activities of extracts. The limitation of this study may be the use of DPPH assay was used to test antioxidant activities, although different substances may involve different mechanisms.

\section{CONCLUSION}

S. punctata extract exhibited significant antioxidant activities equivalent to ascorbic acid, a drug currently in use. In general, S. punctata extract was a strong antioxidant equivalent to ascorbic acid (control). Further investigations of the total phenolic and flavonoid content of extracts will be required. Moreover, the in vivo study will be required in order to substantiate the in vitro findings.

\section{ACKNOWLEDGEMENT}

The study received financial support from the School of Graduate Studies through the Department of Biology, Faculty of Science, Addis Ababa University (AAU). The authors would also like to express honorable thanks to Prof. Zemede Asfaw, who helped us in plant identification. Our heartfelt gratitude extends to Haji Sheh Ali Adem, who was a key informant of a medicinal plant, which we used in the study, and Dr. Adey Feleke, Department of Microbial Cellular and Molecular Biology, AAU for her encouragement and immense financial support for Spectrophotometery training.

\section{CONFLICT OF INTEREST}

The authors declare that they have no competing interests.

\section{ABBREVIATIONS}

IR: Infrared; IC $_{50}$ : half minimum inhibitory concentration; $\mathbf{m g} / \mathrm{kg}$ : milligram per kilogram; DPPH: 2, 2-diphenyl-1-picrylhydrazyl; SD: Standard deviation.

\section{REFERENCES}

1. Elzbieta S, Sulkowski S, Koda M, Zalewski B, Kanczuga-Koda L, Sulkowska M. Lipid peroxidation and antioxidant status in colorectal cancer. World $J$ Gastroenterol. 2005;11(3):403-6.

2. Polterat O. Antioxidants and free radical Scavengers of natural origin. Current Org Chem. 1997,1(4):415-40.

3. Larkins NJ. Free radical biology and pathology. J Equ Vet Sci. 1999;19(2):84-9.

4. Lobo V, Patil A, Phatak A, Chandra N. Free radicals, antioxidants and functional foods: Impact on human health. Pharmacog Rev. 2010;4(8):118-26.

5. Rahman K. Studies on free radicals, antioxidants and co-factors. Clin Interv Aging. 2007;2(2):219-36.

6. Sun Y. Free radicals, antioxidant enzymes and carcinogenesis. Fre Radic Biol Med. 1990;8(6):583-99.

7. Niki E, Shimaski H, Mino M. Antioxidantism-free radical and biological defense. Gakkai Syuppn Center Tokyo. 1994;3-16.

8. Aggarwal A, Gupta S, Sharma RK. Role of oxidative stress in female reproduction. Reprod Biol Endocrinol. 2005;3(1):28-48.

9. Ighodaro OM, Akinloye OA. First line defense antioxidants-superoxide dismutase (SOD), catalase (CAT) and glutathione peroxidase (GPX): Their fundamental role in the entire antioxidant defense grid. Alexandria Med $\mathrm{J}$. 2018;54(4):287-93.

10. Mulay SR, Kulkarni OP, Rupanagudi KV, Migliorini A, Darisipudi MN, Vilaysane A et al. Calcium oxalate crystals induce renal inflammation by NLRP3-mediated IL-1beta secretion. J Clin Invest. 2013;123(1):236-46.

11. Dinnimath BM, Jalalpure SS. Antioxidant and Antiurolithiatic Efficacy of Aerva lanata (L) Fractions by in vitro and in vivo Screening Techniques. Indian J Pharm Educ. 2018;52(3):426-36.

12. Middleton E, Kandaswami C, Theoharides TC. The effects of plant flavonoids on mammalian cells: Implications for inflammation, heart disease and cancer. Pharmacol Rev. 2000;52(4):673-751.

13. Sanchez-Mareno C. Review: Methods used to evaluate the free radical scavenging activity in foods and biological systems. Food Sci Technol Int. 2002;8(3):121-37.

14. Hu FL, Lu RL, Huang B, Ming L. Free radical scavenging activity of extracts prepared from fresh leaves of selected Chinese medicinal plants. Fitoterapia. 2004;75(1):14-23.

15. Sharma OP Bhat TK DPPH antioxidant assay revisited Food Chem. 2009;113(5):1202-5.

16. Bortolomeazzi R, Sebastianutto N, Toniolo R, Pizzariello A. Comparative evaluation of the antioxidant capacity of smoke flavoring phenols by crossing bleaching inhibition, DPPH radical scavenging and oxidation potential. Food Chem. 2007;100(4):1481-9.

17. Fagali N, Catal A. Antioxidant activity of conjugated linoleic acid isomers, linoleic acid and its methyl ester determined by photoemission and DPPH techniques. Biophys Chem. 2008;137(1):56-62.

18. Foti MC, Daquino C, Geraci C. Electron-transfer reaction of cinnamic acids and their methyl esters with the DPPH radical in alcoholic solutions. J Org Chem. 2004;69(7):2309-14 
19. MacDonald-Wicks LK, Wood LG, Garg ML. Review Methodology for the determination of biological antioxidant capacity in vitro: A review. J Sci Food Agric. 2006;86(13):2046-56.

20. Alam MN, Bristi NJ, Rafiquzzaman M. Review on in vivo and in vitro methods evaluation of antioxidant activity. Saudi Pharm J. 2012;21(2):143-52.

21. Brand-Willians W, Cuvelier ME, Berset C. Use of a free radical method to evaluate antioxidant activity. J Food Sci Technol. 1995;28(1):25-30.

22. Rao RR, Tiwari AK, Reddy PP, Babu KS, Ali AZ, Madhusudana K, et al. New furanoflavanoids, intestinal $\alpha$-glucosidase inhibitory and free-radical (DPPH) scavenging, the activity of antihyperglycemic root extract of Derris indica (Lam.). Bioorg Med Chem. 2009;17(14):5170-5.

23. Kaushik J, Tandon S, Gupta V, Nayyar J, Singla SK, Tandon C. Response surface methodology based extraction of Tribulus terrestris leads to an upsurge of antilithiatic potential by inhibition of calcium oxalate crystallization processes. PLoS One. 2017;12(8):e0183218.

24. John JA, Shahidi F. Phenolic compounds and antioxidant activity of Brazil nut (Bertholletia excelsa). J Funct Foods. 2010;2(3):196-209.

25. Abate G. Etse Debdabe: Ethiopian Traditional Medicine. 1st'ed. Demise S. Department of Biology, Science Faculty, Addis Ababa University Press, Addis Ababa. 1989;33-183. (Amharic version).

26. Belay MA. Metsafe Adhnote, Tikmu Mulu Tena Lehulu. Artistic P.E.B/11256. Book of Ethiopian Traditional Medicine, Addis Ababa, Language ("Amharic"). 2014.

27. Khandelwal KR. Practical pharmacognosy: Techniques and experiments.19th ed. Pune: Nirali Prakashan. 2008

28. Kokate CK. Practical Pharmacognosy. New Delhi, India: Vallabh Prakashan. 1991.

29. Evans WC. Trease and Evans Pharmacognosy. Edinburgh, UK: Saunders/ Elsevier Limited. 2009

30. Tiwari P, Kumar B, Kaur M, Kaur G, Kaur H. Phytochemical screening and Extraction: A Review. Internationale Pharmaceutica Sciencia. 2011;1(1):98-106.

31. Hossain MA, AL-Ragmi KA, AL-Mijizy ZH, Weli AM, Al-Riyami Q. Study of total phenol, flavonoids contents and phytochemical screening of various leaves crude extracts of locally grown Thymus vulgaris. Asian Pac J Trop Biomed. 2013;3(9):705-10.

32. Treare GE, Evans WC. Pharmacognosy, 17ed., Bahive Tinal, London. 1985;149.

33. Adebayo-tayo BC, Adegoke AA. Phytochemical and microbial screening of herbal remedies in Akwa Ibom State, South Southern Nigeria. J Med Plant Res. 2008;2(11):306-10

34. Gul R, Jan SU, Faridullah S, Sherani S, Jahan N. Preliminary Phytochemical Screening, Quantitative Analysis of Alkaloids and Antioxidant Activity of Crude Plant Extracts from Ephedra intermedia Indigenous to Balochistan. Sci World J. 2017;7. Article ID 5873648,

35. Roopashree TS, Dang R, Rani RHS, Narendra C. Antibacterial activity of antipsoriatic herbs: Cassia tora, Momordica charantia and Calendula officinalis. Int J Appl Res Nat Prod. 2008:1(3):20-8.
36. Kumar A, llavarasn R, Jayachandran T, Decaraman M, Aravindhan P, Padmanaban N, et al. Phytochemical investigation on a tropical plant. Pak J Nutr. 2009;8(1):83 5 .

37. Vaghasiya $Y$, Dave R, Chanda S. Phytochemical analysis of some medicinal plants from Western region of India. J Med Plant Res. 2011;5(5):567-576.

38. Mittal AK, Kaler A, Uttam CB. Free Radical Scavenging and Antioxidant Activity of Silver Nanoparticles Synthesized from Flower Extract of Rhododendron dauricum. Nano Biomed Eng. 2012:4(3):118-24.

39. Chen YC, Sugiyama Y, Abe N, Kuruto-Niwa R, Nozawa R, Hirota A. DPPH radicalscavenging compounds from Dou Chi, A Soybean fermented food. Biosci Biotechnol Biochem. 2005;69(5):999-1006

40. Huang D, Ou B, Prior R. The chemistry behind antioxidant capacity assays. J Agric Food Chem. 2005;53(6):1841-56

41. Hoetelmans $R M$. IC $C_{50}$ versus $E_{50}$. PK-PD relationships for anti-retroviral drugs Amsterdam: Slotervaart Hospital. 2017. Archived from the original on 2020-1212 via U.S. Food and Drug Administration. http://en.wikipedia.org/wiki// $\mathrm{C}_{50}$.

42. Robak J, Marcinkiewicz E. Scavenging of reactive oxygen species as the mechanism of drug action. Pol J Pharmacol Pharm. 1995;47(2):89-98.

43. Zhao B, Su B, Zhang H, Liu W, Du Q, LiY. Antiurolithiatic effect of ferulic acid on ethylene glycol induced renal calculus in experimental rats. Trop J Pharm Res. 2019;18(1):109-15.

44. Wintola OA, Afolayan AJ. Phytochemical constituents and antioxidant activities of the whole leaf extract of Aloe ferox Mill. Pharmacogn Mag. 2011;7(28):32533.

45. Sikarwar I, Dey YN, Wanjari MM, Sharma A, Gaidhani SN, Jadhav AD Chenopodium album Linn. Leaves prevent ethylene glycol-induced urolithiasis in rats. J Ethnopharmacol. 2017;195:275-82

46. Rajesh RK, Chitra K, Paarakh PM. Aerva lanata (Linn.) Juss. Ex Schult. An Overview. Asian Pac J Trop Biomed. 2011;2:36-40.

47. Bawari S, Sah AN, Tewari D. Antiurolithiatic activity of Daucus carota: An in vitro study. Pharmacog J. 2018;10(5):880-4

48. Pareta SK, Patra KC, Mazumder PM, Sasmal D. Establishing the principle of herbal therapy for antiurolithiatic activity: A Review. J Pharmacol Toxicol. 2011;3(6):321-32.

49. Kifayatullah M, Senguptha P, Mustafa MS, Das SK, Sisugoswomi M. Evaluation of ethanolic extract of Pericampylus glaucus (Lamk.) Merr for total phenolic total flavonoids contents and in vitro antioxidant activity. Int J Pharmacogn Phytochem Res. 2015:7:677-83.

50. Vinson JA, Yong H, Xuchui S, Zubik L. Phenol antioxidant quantity and quality in foods: Vegetables. J Agric Food Chem. 1998;46(9):3630-4

51. Panigrahy SK, Kumar A, Bhatt R. Antioxidant potentials of successive solvent extracts from the unexplored Hedhychium coronarium rhizome. J Food Sc Technol. 2017;54(10):3297-306.

52. Chen YC, Ho CY, Chen LD, Hsu SF, Chen WC. Wu-Ling San formula inhibits the crystallization of calcium oxalate in vitro. Am J Chin Med. 2007:35(03):533-41.

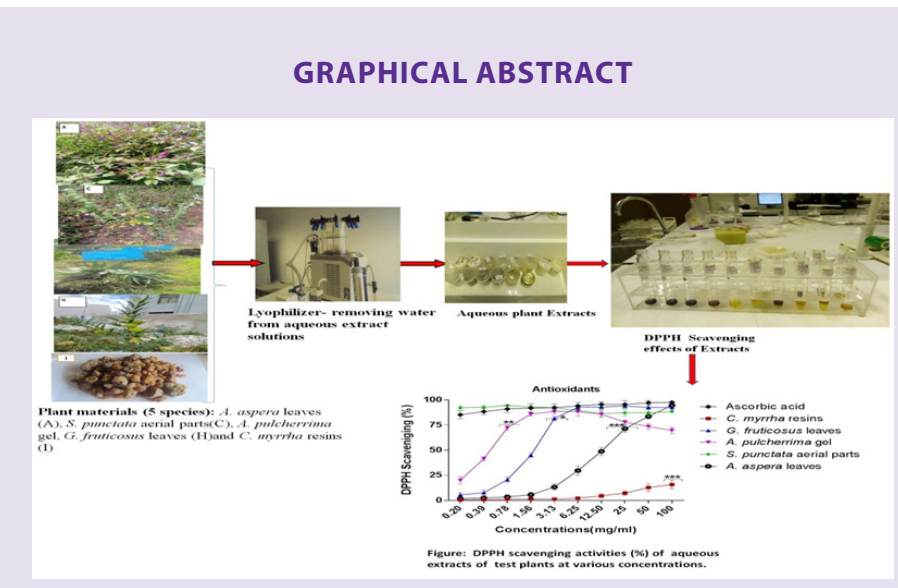

\section{SUMMARY}

DPPH scavenging capacities of $S$. punctata, G. fruticosus, A. pulcherrima and $A$. aspera aqueous extracts were $92.3 \%, 81.6 \%$, $72.3 \%$ and $54.9 \%$, respectively compared to control (Ascorbic acid) showed $87.6 \%, 94.5 \%, 92.3 \%$ and $95.6 \%$, respectively at inhibitory concentrations of $0.20 \mathrm{mg} / \mathrm{ml}, 0.78 \mathrm{mg} / \mathrm{ml}, 3.13 \mathrm{mg} / \mathrm{ml}$ and 12.5 $\mathrm{mg} / \mathrm{ml}$, respectively. The $\mathrm{IC}_{50}$ antioxidant values of $S$. punctata, $A$. pulcherrima, $G$. fruticosus, and $A$. aspera extracts were $0.01 \pm 0.003$ $\mathrm{mg} / \mathrm{ml}, 0.42 \pm 0.047 \mathrm{mg} / \mathrm{ml}, 1.64 \pm 0.147 \mathrm{mg} / \mathrm{ml}$, and $13.51 \pm 1.08 \mathrm{mg} /$ $\mathrm{ml}$, respectively compared to Ascorbic acid $(0.03 \pm 0.007 \mathrm{mg} / \mathrm{ml})$. Thus, the phytoconstituents in $S$. punctata aqueous extract has the best capability to scavenge DPPH free radicals. 


\section{ABOUT AUTHORS}

Beyene Petros (Ph.D.) is a professor of Biology at Addis Ababa University. He attended elementary and high school at local schools in southern Ethiopia. He received his BSc from Addis Ababa University, MS from University of Wisconsin and Ph.D. from Tulane University all in Biology. Beyene joined the staff of Addis Ababa University in 1979 when he became a Lecturer. Later he became a Professor of Biology in 2009. He has more than 120 publications in peer reviewed journals. He has made successful contributions in diseases of public health importance and public health challenges.

Asfaw Debela (Ph.D.) is a researcher at the Ethiopia public health institute. He graduated from Addis Ababa University School of pharmacy with BA degree and obtained his M.Sc. in natural product chemistry. He has also received his Ph.D. in pharmaceutical chemistry from Karl- Franzens university of Graz, Austria, in 2001. He did his post doctoral work at institute of organic and medicinal chemistry, natural products and medicinal chemistry research unity, at Wuzbity University, Germany in 2008. He has published more than 86 scientific publications and co-authored one book. He has made successful contributions in problem solving researches for diseases of public health importance.

Tilahun Alelign has completed his B.Sc. at Bahir Dar University in 2005, and M.Sc. in Biomedical Sciences from Addis Ababa University, Ethiopia in 2010. He has 8 publications, and presented some of these papers at scientific conferences in Ethiopia. His research interests include searching a natural products to cure kidney stone, kidney failure, and related disorders. Currently, he is attending Ph.D. studies at Addis Ababa University, Ethiopia. His research project focuses on traditional medicine to come up with alternative treatment options for kidney calculi.

Cite this article: Alelign T, Debella A, Petros B. Evaluations of Antioxidant Effects of Selected Medicinal Plant Extracts Claimed to Treat Kidney Stone Disease. Free Radicals and Antioxidants. 2020;10(2):63-8. 